\title{
A Study on Development of Entrepreneurship through Effective Human Resource Management Practices - An Empirical Investigation
}

\author{
Article by Emmanuel Appiah \\ PhD in Management, Texila American University \\ E-mail: appiahemmanuel0476@gmail.com
}

\begin{abstract}
As situations and industrial circumstances turns out to be more sophisticate and dynamic, the companies and organizations should adopt supplementary entrepreneurial measures so as to recognize and seize new opportunities and maintaining high quality throughput. In this context, corporate entrepreneurship $(C E)$ is defined as the organizational learning which is motivated by creative thinking, collaboration, coordination and personal dedication. Thus, it can be considered that the HRM (Human resource management) plays an important role for contributing success. This paper provides an analytical research which investigates the connection between HRM practices and CE. This shows that $H R M$ can motivate and contribute to development of entrepreneurship in the company. Therefore, the HR managers must implement developmental policies to assure that their human workforce is appropriately rewarded, compensated and encouraged. This greatly helps in improving their performance which further results in high throughut that guarantees overall profitability and betterment of the organization.
\end{abstract}

Keywords: HRM Practices, IT zone, Corporate Entrepreneurship.

\section{Introduction}

The fundamental objective of Human Resource Management (HRM) policies in any current business trends are focused on people-oriented activities, as the competitive market and constantly changing consumer trends have forced to rethink about the HRM practices. Human Resources (HR) can be considered as the aptitudes, skills, knowledge, wisdom, creative proficiencies, spontaneity and adaptability derived from the population or the entirety of all intrinsic capabilities, gained knowledge, expertise and skills as characterized in the aptitudes and talents of its employees. HRM is a vital functional component of management and it is mainly focused on the management of the Human Resources and workforce of the organization. The essential goal of the HRM is the building and retaining healthy and progressive employee connections for fulfilling the mission of the company.

Additionally, HRM is focused on achieving the most ideal outcomes through effective employee practices in the company. Tatikonda, M.V., and Rosenthal, S.R. (2000) contend that HR practices support an adequate set of activities and tasks that needs variety of skill-set and expertise, ranging from remuneration and employee benefits (highly quantitative) to employee relations (highly qualitative). As a result, there are constant debate about whether these practices must be integrated with organizational schemes and plans under new technological advances and practical working conditions. Plummer, P., and Taylor, M. (2004) asserted that a business setting that assures least benefits and profits are not an adequate condition for survival of the organization. Rather, it must provide a social foundation, over which, the individuals and groups can build a progressive work environment.

Likewise, entrepreneurship is also described to be a course of creating a new object of value through constant dedication, determination, while understanding the associated risks and consequences in terms of economy and social risks, and finally enjoying the benefits through financial gains, personal gratification and liberation (Kuratko, D.F., Hornsby, J.S., and Goldsby, M.G. 2004).This procedure empowers the business in creating value by recognizing the market opportunities and making remarkable mixtures of available assets to seek after those opportunities (Allen, S.D., Link, A.N, and Rosenbaum, D.T. 2007). 
This indicates that for a company to survive the harsh and challenging business environment there is a compulsive requirement for capturing the context of human resources in supporting the development and enhancement of entrepreneurship in the business firms for achieving good market results.

Dakhli, M. and De Clercq, D. (2007) highlighted that HRM practices doesn't influence the organizational performance straightforwardly, rather it assists in assembling intellectual capital that can result in better organizational value. In this manner, so as to appreciate this admirable result of entrepreneurship, each business association human capital must be well planned, sorted out, organized, chosen, prepared, created, evaluated and appropriately remunerated in the best possible means that will bring about the progress and advancement of the desirable core skills and aptitudes which provides great assistance to create good organizational value. Therefore, the organizations must plan its human capital appropriately, so that it will create a strong foundation of competitive advantage (Honig, B. 2001)

In current context of analysis, this study aims to examine the effect of HRM policies on the entrepreneurship development on a typical business environment. The rest of the sections in this paper present a brief review on current literature, research trends, results, conclusion, and suggestions/recommendations.

\section{Aims and objectives}

The aim and objectives of this work is not to replicate any of the already made work conducted which emphasizes on the work of human resource Management. This study aims to critically analyze some of the various ways human resources work is being initiated in our work places which will ensure future growths of human relation. However, the evidence is lacking in relation from knowledge to understanding and implementation of human relation guidelines. The aim of the studies will also identify learning needs of HRM unit in providing an evidence base approach to the managing of human relation.

\section{Review of literature}

Ende, J.V.D., Wijnberg N., Vogels, R., and Kerstens, M. (2003) presented their work, titled "Key HRM, development and business endeavor association; A cross-local relative model". In this work, they suggested that the relation between the HRM strategies, entrepreneurship model and innovation, dictates the overall entrepreneurial performance (Ende, J.V.D., Wijnberg N., Vogels, R., and Kerstens, M., 2003).

Anker, L.V. (2006), published a paper on "HRM in India: Where from and Where to?" The researchers have presented a solid evidence of the financial companies and managerial concepts antique Indian sources with persistent customs and traditions that believes in the context of existing challenges. They further focused on the "demographic dividend" which explained about a new trend in the HR thoughts and practices in India (Anker, L.V. 2006).

Hornsby, J.S., Kuratko, D.F., and Zahra, S.A. (2002), presented a paper entitled "Displaying commonplace HRM procedures in China: An enterprise perspective". They concentrated on the relation between two wide range HRM practices, organizational performance, strategic entrepreneurship, etc., for the purpose of boosting cross-regional HRM approach model. This promised to help Chinese companies to expand their business and gain global presence (Hornsby, J.S., Kuratko, D.F., and Zahra, S.A. 2002)

Lumpkin, G.T., and Dess, G.G. (2001) published his work titled "sustaining Intrapreneurship: Think like a VC, demonstration like a business visionary". The author has highlighted the tactics to boost entrepreneurial approach among the corporate administrators in order to assist them in investigating the approaches such as a VC and afterward to carry out with the primal and uncontrolled passion of an entrepreneur (Lumpkin, G.T., and Dess, G.G. 2001).

"The quality of HR hones in India and their consequences for worker vocation achievement, execution, and potential", was published by Marvel, M.R., and Lumpkin, G.T. (2007). This work gives an idea of innovative career administration techniques, which is much needed for the development of internal entrepreneurship (Marvel, M.R., and Lumpkin, G.T. (2007).). 
Shrader, R. and Siegel, D.S. (2007), presented a paper on "The relationship between trust, HRM practices and firm performance". This works suggests the roles of HRM in establishing supportable entrepreneurship and describe the relevant HRM techniques, practices and strategies.

During a survey of existing research on the HRM practices and Corporate Entrepreneurship, it was found that there were no works in IT sector particularly in Karnataka. The IT industry has turned out to be a vast economic power house of India, which provides several types of career opportunities to numerous individuals. In present scenario, the IT industry has progressed into an improbable, belligerent and they demand for efficient human resources practices.

In current trends of IT business, the industry needs talented man power that can be more creative and think over the limit to come up with fresh ideas and concepts for rapid business development and profitability. In such situation, HRM strategies become essential to encourage entrepreneurial behavior and development. We contend that various HR roles and responsibilities like staffing, training, career counseling, performance evaluation, remuneration, motivation, etc., have a profound influence on the advancement of entrepreneurial behavior in IT employees. Our supposition is investigated through survey and the results are analyzed to check the validity of our hypothesis.

A few research works concentrate on the effect of HRM strategies on the advancement and innovative development of entrepreneurship, which is the crucial purpose of business enterprise. In a particular research, Zahra, S.A., and Covin, J.G. (1995) inspected the connection amongst HRM and advancement in Greece. This study described that the human capital investment incentives for innovation are of critical significance for overall technological advancement. Likewise, Kemelgor, B.H. (2002) presented a new HRM strategy which suggested that teamwork, collaboration and performance related compensation will induce a collaboration influence on innovation when they are implemented together.

\section{Research methodology}

This research employs quantitative research approach to accumulate first-hand information. This study is an empirical investigation based on exploratory study design followed by contributory research to study the HRM practices that influence the corporate entrepreneurial behavior among personnel working for IT sectors, Karnataka, India.

\section{Data sources}

For the purpose of accumulating data pertaining to HR practices, and developmental measures for employee and organization, both primary and secondary data sources have been used such as books, magazines, internet sources, e-books, conference proceedings, academic articles, company reports and many more.

Primary data can be gathered through survey questionnaires by framing six closed ended questions. Likert scale rating key is used for the survey questionnaire, such as $1=$ strongly disagree, 2 =disagree, $3=$ neutral $4=$ agree $5=$ strongly agree,. Secondary data can be gathered through existing sources like, current research, journals, websites, books, Conference proceedings, Articles, company reports, Newspapers, magazines, etc.

\section{Sampling framework}

The process of primary data accumulation is carried out through Simple Random sampling method. 51 participants were selected from 3 different IT companies from Karnataka, India, and questionnaires are distributed among them. These participants are mostly from HR department.

\section{Data analysis}

With the help of SPSS software, Pearson correlation, Regression and ANOVA statistical analysis techniques are implemented, which helps in verifying the influence of HRM practices towards symbiotic development of employee and organization. 
DOI: 10.21522/TIJMG.2015.SE.19.01.Art019

ISSN: $2520-310 \mathrm{X}$

\section{Results}

Correlation analysis

\begin{tabular}{|c|c|c|c|c|c|c|c|c|}
\hline \multicolumn{9}{|c|}{ Correlations } \\
\hline \multirow{4}{*}{ RS } & & RS & $\mathrm{TN}$ & $\mathrm{CF}$ & CGO & APAM & $\mathrm{CR}$ & IB \\
\hline & $\begin{array}{l}\text { Pearson } \\
\text { Correlation }\end{array}$ & 1 & $.416^{* *}$ & .209 & .242 & $.422^{* *}$ & $.551^{* *}$ & $.538^{* *}$ \\
\hline & Sig. (2-tailed) & & .002 & .142 & .087 & .002 & .000 & .000 \\
\hline & $\mathrm{N}$ & 51 & 51 & 51 & 51 & 51 & 51 & 51 \\
\hline \multirow[t]{3}{*}{ TN } & $\begin{array}{l}\text { Pearson } \\
\text { Correlation }\end{array}$ & $.416^{* * *}$ & 1 & $.550^{* *}$ & $.721^{* *}$ & $.697^{* *}$ & $.645^{* * *}$ & $.904^{* *}$ \\
\hline & Sig. (2-tailed) & .002 & & .000 & .000 & .000 & .000 & .000 \\
\hline & $\mathrm{N}$ & 51 & 51 & 51 & 51 & 51 & 51 & 51 \\
\hline \multirow[t]{3}{*}{$\mathrm{CF}$} & $\begin{array}{l}\text { Pearson } \\
\text { Correlation }\end{array}$ & .209 & $.550^{* *}$ & 1 & .263 & $.472^{* *}$ & $.480^{* * *}$ & $.604^{* *}$ \\
\hline & Sig. (2-tailed) & .142 & .000 & & .062 & .000 & .000 & .000 \\
\hline & $\mathrm{N}$ & 51 & 51 & 51 & 51 & 51 & 51 & 51 \\
\hline \multirow[t]{3}{*}{ CGO } & $\begin{array}{l}\text { Pearson } \\
\text { Correlation }\end{array}$ & .242 & $.721^{* *}$ & .263 & 1 & $.518^{* *}$ & $.481^{* *}$ & $.712^{* *}$ \\
\hline & Sig. (2-tailed) & .087 & .000 & .062 & & .000 & .000 & .000 \\
\hline & $\mathrm{N}$ & 51 & 51 & 51 & 51 & 51 & 51 & 51 \\
\hline \multirow[t]{3}{*}{ TPAS } & $\begin{array}{l}\text { Pearson } \\
\text { Correlation }\end{array}$ & $.422^{* * *}$ & $.697^{* *}$ & $.472^{* *}$ & $.518^{* *}$ & 1 & $.538^{* * *}$ & $.808^{* * *}$ \\
\hline & Sig. (2-tailed) & .002 & .000 & .000 & .000 & & .000 & .000 \\
\hline & $\mathrm{N}$ & 51 & 51 & 51 & 51 & 51 & 51 & 51 \\
\hline \multirow[t]{3}{*}{ CR } & $\begin{array}{l}\text { Pearson } \\
\text { Correlation }\end{array}$ & $.551^{* *}$ & $.645^{* *}$ & $.480^{* *}$ & $.481^{* *}$ & $.538^{* *}$ & 1 & $.743^{* *}$ \\
\hline & Sig. (2-tailed) & .000 & .000 & .000 & .000 & .000 & & .000 \\
\hline & $\mathrm{N}$ & 51 & 51 & 51 & 51 & 51 & 51 & 51 \\
\hline \multirow[t]{3}{*}{$\mathrm{IB}$} & $\begin{array}{l}\text { Pearson } \\
\text { Correlation }\end{array}$ & $.538^{* * *}$ & $.904^{* *}$ & $.604^{* *}$ & $.712^{* *}$ & $.808^{* * *}$ & $.743^{* *}$ & 1 \\
\hline & Sig. (2-tailed) & .000 & .000 & .000 & .000 & .000 & .000 & \\
\hline & $\mathrm{N}$ & 51 & 51 & 51 & 51 & 51 & 51 & 51 \\
\hline
\end{tabular}

Pearson correlation method was applied to prove the correlation between practices of human resource management and corporate entrepreneurial behavior. Pearson correlation of corporate entrepreneurial behavior with practices of human resource management that is Recruitment and Selection $(\mathrm{r}=.538)$ Training Needs $(\mathrm{r}=.904)$, Constructive Feedback $(\mathrm{r}=.604)$, Providing Career Growth Opportunities $(\mathrm{r}=.712)$, Apparent Performance Appraisal Method( $\mathrm{r}=.808)$, Compensation Remuneration( $\mathrm{r}=.743)$, show signs of an active correlation. The fallout point out that each and every variables are mathematically significant at $(\mathrm{p}<.05)$. 


\section{Regression analysis}

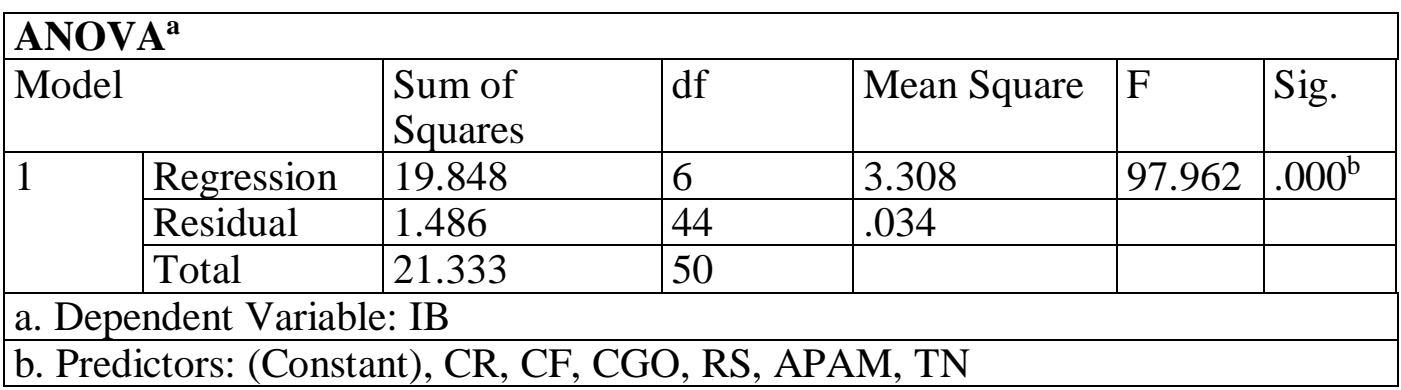

The above ANOVA table represents the significant $\mathrm{P}$ value as $<0.05$; this point towards that the model is significant statistically.

\section{Regression analysis model summary}

\begin{tabular}{|l|l|l|l|l|l|l|l|l|}
\hline \multicolumn{2}{|l|}{ Model Summary } \\
\hline Model
\end{tabular}

\section{Result analysis}

Coefficient of resilience particularly Adjusted $\mathrm{R}^{2}$ Value $(0.921)$ shows $92 \%$ difference in is development of corporate entrepreneurial behavior attributable to the projected model. It confirms that practices of human resource management i.e. Recruitment and Selection, Training Needs, Constructive Feedback, Providing Career Growth Opportunities, Apparent Performance Appraisal Method, Compensation Remuneration have a fruitful impact on rising corporate entrepreneurial behavior among human resources. Accordingly, it is documented that independent variables openly HRM practices contribute hopefully towards renovation in the dependent variable i.e. corporate entrepreneurial behavior.

\section{Conclusion}

The major goal of this study was to do research on the practices of human resource management that impact the corporate entrepreneurial behavior among Techies. The mathematical upshot obtained in this study established that mechanisms of HRM have a significant positive impact on development of corporate entrepreneurial behavior among human resources. On the most successful practices of human resource management that is training initiated to have direct impact on development of corporate entrepreneurial behavior. This end result insisted that when organizations have highly developed level of training, it will perk up the development of employee's vital capabilities and their potential to increase knowledge. Employees are proficient to form new perceptive and innovative ideas that will be useful for organizational innovation.

Performance appraisal, on the other hand found to have direct impact on development of corporate entrepreneurial behavior. Fair and apparent performance appraisal methods absolutely will excite employees towards their jobs. High drive will make easy to enhance employee's passion to bring about innovative ideas in an attempt to boost organizational innovation.

Practices of HRM for instance career administration, compensation remuneration, recruitment practices were found to have direct positive impact on development of corporate entrepreneurial behavior among employees. 
DOI: 10.21522/TIJMG.2015.SE.19.01.Art019

ISSN: $2520-310 \mathrm{X}$

\section{Recommendations}

The obtained experimental results provide several substantial managerial propositions. First and foremost, the administrator can make every attempt to enrich product innovation by providing necessary training programs related to technology of the product. Administrators must establish a way to permit the employees to gain and absorb assorted varieties of skills and knowledge from various sources through company partners and internal and external training schedules. They must further facilitate sharing and transfer of knowledge from one person to other, within the company. With proper facilities, the employees can gain more skills and become more efficient in addressing work related issues. The administrators must encourage the employees to gain, transfer, and apply their skill set and knowledge, to fulfill the criteria for positive performance evaluation, as it can get very competitive. Hence, such knowledge enrichment through proper training will ensure greater talents and innovation skills. Secondly, it is essential for IT industries to carry out performance evaluation on their employees. This helps in strengthening the devotion and enthusiasm of employees, and keeps them motivated.

\section{References}

[1]. Allen, S.D., Link, A.N, and Rosenbaum, D.T. 2007. Entrepreneurship and human capital: Evidence of patenting activity from the academic sector, Entrepreneurship Theory and Practice 31(6): 937-951.

[2]. Anker, L.V. 2006. Absorptive capacity and innovative performance: A human capital approach, Economics of Innovation and New Technology 15(4-5): 507-517

[3]. Dakhli, M. and De Clercq, D. 2007. Human capital, social capital, and innovation: A multicountry study, Entrepreneurship \& Regional Development, 16: 107-128

[4]. Ende, J.V.D., Wijnberg N., Vogels, R., and Kerstens, M. 2003. Organizing innovative projects to interact with market dynamics: A co evolutionary approach, European Management Journal, 21(3): 273-284.

[5]. Hornsby, J.S., Kuratko, D.F., and Zahra, S.A. 2002. Middle managers' perception of the internal environment for corporate entrepreneurship: Assessing a measurement scale, Journal of Business Venturing, 17: 253-273.

[6]. Honig, B.2001. Learning strategies and resources for entrepreneurs and intrapreneurs, Entrepreneurship Theory and Practice, 26(1): 21-35.

[7]. Kemelgor, B.H. 2002. A comparative analysis of corporate entrepreneurial orientation between selected firms in the Netherlands and the USA, Entrepreneurship \& Regional Development, 14: 67- 87.

[8]. Kuratko, D.F., Hornsby, J.S., and Goldsby, M.G. (2004). Sustaining corporate entrepreneurship: modelling perceived implementation and outcome comparisons at organizational and individual levels, International Journal of Entrepreneurship and Innovation, 5(2): 77-89.

[9]. Lumpkin, G.T., and Dess, G.G. 2001. Linking two dimensions of entrepreneurial orientation to firm performance: The moderating role of environment and industry life cycle, Journal of Business Venturing, 16(3): $429-451$

[10]. Marvel, M.R., and Lumpkin, G.T. 2007. Technology entrepreneurs' human capital and its effects on innovation radicalness, Entrepreneurship Theory and Practice, 31(6): 807-828.

[11]. Plummer, P., and Taylor, M. 2004. Entrepreneurship and human capital, Journal of Small Business and Enterprise Development, 11(4): 427-439. 